\title{
Immunohistochemical expression of macrophages in chronic periapical lesions
}

\author{
Expressão imunohistoquímica de macrófagos em lesões periapicais crônicas \\ Expresión inmunohistoquímica de macrófagos en lesiones periapicales crónicas
}

Received: 05/29/2021 | Reviewed: 06/07/2021 | Accept: 06/10/2021 | Published: 06/24/2021

Zilda Betânia Barbosa Medeiros de Farias
ORCID: https://orcid.org/0000-0001-9549-2260
University of Pernambuco, Brazil
E-mail: zilda.mfarias@ upe.br
Jade de Souza Cavalcante
University of Pernambuco, Brazil
E-mail: jadeahj@ gmail.com
Anne Caroline de Lima
ORCID: https://orcid.org/000-0003-1044-2323
University of Pernambuco, Brazil
E-mail: lima_caroline84@ hotmail.com
ORCID: https:/orcid.org/0000-0003-3914-9745
Emanuel Sávio de Souza Andrade
ORCID: https://orcid.org/0000-0003-2165-4217
University of Pernambuco, Brazil
E-mail: emanuel.savio@ upe.br
Márcia Maria Fonseca da Silveira
ORCID: https://orcid.org/0000-0002-2611-5661
University of Pernambuco, Brazil
E-mail: marcia.silveira@ upe.br
Ana Paula Veras Sobral
University of Pernambuco, Brazil
E-mail: ana.sobral@upe.br

\begin{abstract}
Objective: To analyze the expression of macrophages in periapical granulomas (PGs) and radicular cysts (RCs). Methodology: We selected 264 cases of chronic periapical lesions stored at the Laboratory of Pathology, Dental School of Pernambuco (FOP)/UPE, including 89 PGs and 175 RCs. Seventy-nine cases, 23 PGs and 56 RCs, were submitted to immunohistochemical analysis by the streptavidin-biotin method using anti-CD68 antibody. The chi-square and Fisher's exact tests were used to determine the existence of associations with categorical and clinical variables, adopting a $95 \%$ confidence level $(p \leq 0.05)$. Results: We observed immunoexpression of CD68 in $83 \%$ of cases. The number of CD68+ cells (score 3 or 4) was higher in PGs, with predominantly intense staining. Significant differences in the number of CD68+ cells and staining intensity were observed between the chronic periapical lesions analyzed. Conclusion: The presence of CD68+ cells in periapical tissues may indicate the development, maintenance and/or severity of the inflammation-mediated immune response, which is more intense in PG.
\end{abstract}

Keywords: Periapical granuloma; Radicular cyst; Immunohistochemistry; CD68 macrophage.

\section{Resumo}

Objetivo: Analisar a expressão de macrófagos em granulomas periapicais e cistos radiculares. Metodologia: Foram selecionados 264 casos de lesões periapicais crônicas dos quais 89 eram granulomas periapicais (GPs) e 175 cistos radiculares (CRs), registrados no Laboratório de Patologia da Faculdade de Odontologia de Pernambuco FOP/UPE. Foram utilizados para análise imuno-histoquímica através da técnica da estreptoavdina-biotina utilizando o anticorpo anti CD68, para tanto, 79 casos, sendo 23 de granulomas periapicais e 56 de cistos radiculares. Os testes Qui-Quadrado e Exato de Fisher foram empregados para verificar se existia associação das variáveis categóricas e clínicas, com 95\% de confiança $(\mathrm{p} \leq 0,05)$. Resultados: Verificamos imunoexpessão da proteína CD68+ em $83 \%$ dos casos. As lesões de GP apresentaram maior número de células CD68+, (com escore variando de 3 a 4) com marcação, predominantemente, intensa. Constatamos diferenças significativas em relação a quantidade de células CD68+ e a intensidade desta marcação nas lesões periapicais crônicas analisadas Conclusão: A presença de células CD68+ nos tecidos periapicais podem representar o desenvolvimento, manutenção e/ou severidade da resposta imune mediada à inflamação, sendo essa mais intensa em GP.

Palavras-chave: Granuloma periapical; Cisto radicular; Imuno-histoquímica; Macrófagos CD68. 


\begin{abstract}
Resumen
Objetivo: Analizar la expresión de macrófagos en granulomas periapicales y quistes radiculares. Metodología: Fueron seleccionados 264 casos de lesiones periapicales crónicas de los cuales 89 eran granulomas periapicales (GPs) y 175 quistes radiculares (CRs), registrados en el Laboratorio de Patología de la Facultad de Odontología de Pernambuco FOP/UPE. Fueron utilizados para análisis inmunohistoquímica a través de la técnica de la estreptoavdina-biotina utilizando el anticuerpo anti CD68, para tanto, 79 casos, siendo 23 de granulomas periapicales y 56 de quistes radiculares. Los testes Chi-Cuadrado y Exacto de Fisher fueron empleados para verificar si existía asociación de las variables categóricas y clínicas, con $95 \%$ de confianza $(\mathrm{p} \leq 0,05)$. Resultados: Verificamos inmunoexpensión de la proteína CD68+ em 83\% de los casos. Las lesiones de GP presentaron mayor número de células CD68+, (con puntaje variando de 3 a 4) con marcación, predominantemente, intensa. Verificamos diferencias significativas en relación a la cantidad de células CD68+ y la intensidad de esta marcación en las lesiones periapicales crónicas analizadas Conclusión: La presencia de células CD68+ en los tejidos periapicales pueden representar el desarrollo, manutención y/o severidad de la respuesta inmune mediada a la inflamación, siendo esa más intensa en GP.
\end{abstract}

Palabras clave: Granuloma periapical; Quiste radicular; Inmunohistoquímica; Macrófagos CD68.

\title{
1. Introduction
}

Periapical granulomas (PGs) and radicular cysts (RCs) are osteolytic inflammatory lesions that commonly affect the jaws (Koivisto et al. 2012), in which a complex inflammatory immune response leads to the bone destruction (Cavalla et al. 2021; Maia et al. 2020). These lesions are characterized by the presence of a mononuclear inflammatory infiltrate consisting of lymphocytes, plasma cells, mast cells, and macrophages (Leonardi et al. 2005). Macrophages are the predominant inflammatory cells in chronic periapical lesions (Metzger, 2000) where they exert a protective effect. In addition, these cells mediate the development and progression of the inflammatory response through the production of cytokines (Marton \& Kiss, 2000).

The development and persistence of chronic periapical lesions is a dynamic and complex process whose pathogenesis is intimately linked to the host immune response (Álvares et al. 2017; Galler et al. 2021), as well as to the type of microorganism involved since the bacterial composition in the infected root canal can influence macrophage polarization (Mantovani et al. 2007; $\mathrm{Li}$ et al. 2013). However, this polarization is only one factor of the immune response in chronic periapical lesions (Weber et al. 2018). Many studies reinforce the role of macrophages in the pathogenesis of these chronic lesions (Lin et al. 2000; Bracks et al. 2014; Rodini \& Lara, 2001), suggesting that these cells actively participate in the development and maintenance of local inflammation in PG and RC.

In view of the above, the objective of this study was to analyze the expression of CD68+ cells in PG and RC in an attempt to understand the role of macrophages in the inflammatory process associated with the progression of these lesions.

\section{Methodology}

\section{Sample selection and study design}

The study was approved by the Ethics Committee of the University of Pernambuco (Protocol No. 0058.0.097.000-08) and was conducted in accordance with the guidelines of the Declaration of Helsinki.

Among 264 cases of chronic periapical lesions (PG and RC) properly diagnosed by histopathological examination and registered at the Prof. Rildege Accioly Laboratory of Surgical Pathology, Dental School of Pernambuco, 79 (30\%) were selected for immunohistochemistry, including 23 PGs and $56 \mathrm{RCs}$ ( $8.7 \%$ and $21.2 \%$ of all cases, respectively), maintaining the proportion of the incidence of the lesions found in the sample. Since immunohistochemical analysis is a qualitative assessment, this numerical difference does not influence the results obtained.

The demographic (age and sex) and clinical data (anatomical location of the periapical lesion) were obtained from the biopsy referral forms stored in the archives of the laboratory. 


\section{Immunohistochemical method}

Paraffin-embedded samples were cut into 3- $\mu \mathrm{m}$ thick sections, which were mounted on glass slides prepared with 3aminopropyltriethoxy-silane adhesive (Sigma Chemical Co., St. Louis, MO, USA). Anti-CD68 (Dako, Carpinteria, CA, USA) was used as primary antibody (1:50,30 minutes at room temperature). The sections were incubated with the secondary antibody (LSAB kit, Dako [Carpinteria, CA, USA]; 30 minutes at room temperature), followed by the addition of the streptavidin-biotin complex (LSAB kit, Dako [Carpinteria, CA, USA]; 30 minutes at room temperature). The reaction was developed with 3,3'diaminobenzidine ( $30 \mathrm{mg} / 100 \mathrm{ml}$ PBS $+0.6 \mu \mathrm{l}$ of $6 \% \mathrm{H}_{2} \mathrm{O}_{2}$; Sigma Chemical Co., St. Louis, MO, USA) for 5 minutes. The sections were counterstained with Mayer's hematoxylin (Biopack) and mounted on slides with Entelan (Merck).

\section{Immunohistochemical analysis}

The slides were analyzed by a pathologist with more than 20 years of experience. The immunohistochemical staining pattern and distribution of the CD68 antigen were evaluated by light microscopy (E200 Nikon Biological Microscope, Japan). For determination of the immunohistochemical expression pattern of the protein studied, the sections were classified regarding the presence (+) or absence (-) of the antigen. For quantitative analysis, the positive cases were classified according to the intensity of staining as follows: weak (+), moderate (++), intense (+++), and very intense (++++). In addition, the distribution of staining was classified as focal or diffuse. For semi-quantitative analysis, immunoexpression scores were attributed as shown in Table 1. As negative controls, the samples were treated as described previously, except that the primary antibody was omitted and replaced with non-immune murine IgG1 (X-0931, Dako) or 1\% BSA-PBS for the antibody studied. Fragments of oral mucosa and bone, tissues known to be positive for the antigen studied, served as positive controls.

\section{Statistical analysis}

The data were analyzed with the STATA/SE 12.0 and Excel 2010 programs. The chi-square and Fisher's exact tests were used to determine the existence of an association between the variables studied. The tests were applied assuming a $95 \%$ confidence level $(\mathrm{p} \leq 0.05)$.

\section{Results}

\section{Clinical and demographic data}

Among the 264 cases of chronic periapical lesions studied, $33.71 \%$ ( $n=89$ ) corresponded to PG, while $66.29 \%(n=175)$ were RCs. There was a predominance of females, but the number of RCs was higher among males $(46,9 \%, \mathrm{n}=82)$. This difference was statistically significant $(\mathrm{p}=0.023)$. A higher prevalence of chronic periapical lesions was observed among patients between the second and fifth decades of life, with a peak of RC and PG in the third (22.28\%) and fourth decade (32.38\%), respectively. Regarding anatomical location, the maxilla was the jawbone with the largest number of cases. However, evaluation of the RC cases showed a higher prevalence in the upper maxilla $(60 \%, \mathrm{n}=104)$, with a predominance in the anterior region $(53.85 \%, \mathrm{n}=56)$. Periapical granulomas were also more frequent in the maxilla $(53.93 \%, \mathrm{n}=48)$ and anterior region $(56.25 \%, \mathrm{n}=27)$ (Table 1$)$. 
Table 1. Distribution of radicular cysts and periapical granulomas according to the clinical variables studied (sex, location). Data from the Laboratory of Oral Pathology, FOP.

\begin{tabular}{|c|c|c|c|c|}
\hline \multirow[b]{2}{*}{ Variable } & & \multicolumn{2}{|c|}{ Chronic periapical lesions } & \multirow[b]{2}{*}{$\mathbf{p}$} \\
\hline & & $\begin{array}{c}\text { Radicular cyst } \\
\text { n }(\%)\end{array}$ & $\begin{array}{c}\text { Periapical granuloma } \\
\text { n }(\%)\end{array}$ & \\
\hline \multicolumn{5}{|l|}{ Sex } \\
\hline & Male & $82(46.9)$ & $28(31.5)$ & $0.023 *$ \\
\hline & Female & $93(53.1)$ & $61(68.5)$ & \\
\hline \multicolumn{5}{|l|}{ Site } \\
\hline & Maxilla & $104(64.6)$ & $48(60.8)$ & $0.562 *$ \\
\hline & Mandible & $57(35.4)$ & $31(39.2)$ & \\
\hline \multicolumn{5}{|l|}{ Maxilla } \\
\hline & Anterior & $56(58.9)$ & $27(56.2)$ & $0.758 *$ \\
\hline & Posterior & $39(41.1)$ & $21(43.8)$ & \\
\hline \multicolumn{5}{|l|}{ Mandible } \\
\hline & Anterior & $8(14.8)$ & $4(13.8)$ & $1.0 * *$ \\
\hline & Posterior & $46(85.2)$ & $25(86.2)$ & \\
\hline
\end{tabular}

Clinical variables are given as number and percentage. $\mathrm{p} \leq 0.05:(*)$ chi-square test, $\left({ }^{* *}\right)$ Fisher's exact test. Source: Authors.

\section{Immunohistochemical expression}

Among the 23 PG cases analyzed, CD68-immunostained cells were observed in $30.43 \%$ (n=7), with score 4 (Figure 1A). Staining intensity ranged from moderate to intense (Figure 1B), with diffuse distribution of these cells in connective tissue. Six cases (26\%) received score 3, with intensity ranging from moderate to intense and diffuse distribution in connective tissue. Score 2 was attributed to $17.39 \%$ of the cases $(n=4)$. The cells were intensely stained, with focal and diffuse distribution in connective tissue. One case $(4.34 \%)$ received score 1 , with some cells exhibiting focal expression in connective tissue (Table 2). 
Table 2. Percentage of CD68+ cells (score, staining intensity and distribution) in periapical granulomas and radicular cysts.

\section{Chronic periapical lesions}

Variable

Periapical granuloma

n $(\%)$
Radicular cyst

n $(\%)$

Score

0

2

3

4

Intensity

$\begin{array}{cc}- & 5(21.7) \\ + & 1(4.3) \\ ++ & 4(17.4) \\ ++ & 13(56.6)\end{array}$

Diffuse

14 (77.8)

Focal

$4(22.2)$

\section{Distribution}

$8(14.3)$

$37(66.0)$

1 (1.8)

7 (12.5)

$3(5.4)$
$<0.001 * *$

8 (14.3)

$<0.001$ **

37 (66.0)

$1(1.8)$

10 (17.9)

$\mathrm{p}<0.05 .(* *)$ Fisher's exact test. There was a significant difference in score and intensity between the groups studied. Source: Authors.

Table 3. Scoring of the percentage of stained cells.

\begin{tabular}{|c|c|}
\hline Score & Description \\
\hline 0 & No stained cells \\
\hline 1 & $0-10 \%$ stained cells - weak \\
\hline 2 & $10-25 \%$ stained cells - moderate \\
\hline 3 & $25-50 \%$ stained cells - intense \\
\hline 4 & $>50 \%$ stained cells - very intense \\
\hline
\end{tabular}

Source: Authors.

Among the 56 cases of RCs analyzed, immunoexpression was observed in 66\% (37 cases), with intense staining (Figure 1C), score 1, and diffuse distribution in connective tissue in $89 \%$ of the cases. Stained cells were noted in the region of the cystic epithelium (Figure 1D). Score 4 was attributed to $5.35 \%$ of the cases (4 cases), with diffuse expression in connective tissue and intense staining (Figure 1E; Table 3). Immunostaining of multinucleated giant cells was observed in some cases at the periphery of images that were negative for cholesterol crystals found in the cystic capsule (Figure 1F). A significant difference in "score" and "intensity" was observed between the groups analyzed (Table 2). 
Figure 1. A - Score 4, immunostained cells diffusely distributed in connective tissue of periapical granuloma (PG) (IHC, CD68+, 40X). B - Intense cytoplasmic staining in macrophages of PG (IHC, CD68+, 100X). C - Score 1, intense cytoplasmic staining in connective tissue of the cystic capsule of a radicular cyst (RC) (IHC, CD68+, 100X). D - Immunoexpression in the lining cystic epithelium of RC (IHC, CD68+, 10X). E - Score 4, immunostained cells diffusely distributed in connective tissue of RC (IHC, CD68+, 40X). F - Immunoexpression in giant cells amidst cholesterol crystal-negative images in RC (IHC, CD68+, 40X).
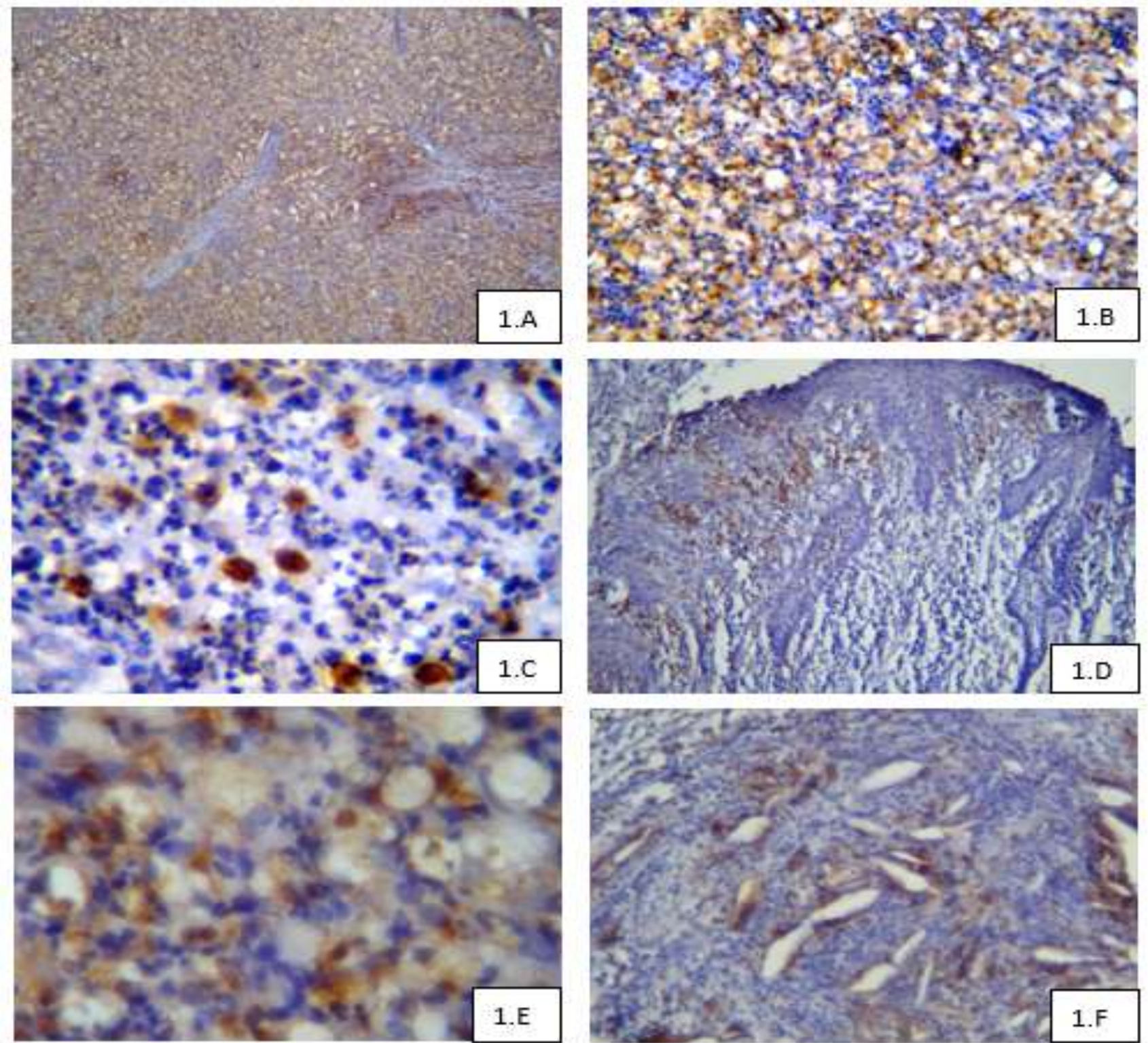

Source: Authors.

\section{Discussion}

The presence of CD68+ macrophages has been described in chronic periapical lesions (Rodini \& Lara, 2001). Researchers have reported a significant increase in the number of macrophages in human RCs (Bracks et al. 2014), as well as in chronic periapical lesions induced in rats (Lin et al. 2000). In the present study, PGs exhibited a more intense inflammatory infiltrate than RCs, with the difference being statistically significant (Table 3). Weber et al. (2018) and Azeredo et al. (2017) found no significant difference in the expression of CD68 between PGs and RCs. According to Cassanta et al. (2017), the larger number of CD68+ cells demonstrates the presence of macrophages in the inflammatory infiltrate that constitutes PG and RC. 
Alvares et al. (2018) suggested the inflammatory process that affects periapical tissues to be the result of a complex reaction, which directly depends on the cellular relationship between the immune system and microorganisms present in the root canal system. Structural and physiological alterations occur in periapical tissues in response to this process as a result of persistent immunoinflammatory events (Alvares et al. 2018).

Our results differ from the studies of Rodini and Lara (2001); Liapatas et al. (2003); Rodini, Batista and Lara (2004) in terms of the number of CD68+ cells in the lesions, showing a larger number of stained cells in PG (score 4). Diffuse distribution of CD68+ cells was observed in the connective tissue of PGs and RCs, corroborating the findings of Suzuki et al. (2001). Bracks et al. (2014) and Cassanta et al. (2017) detected a larger number of CD68+ cells in areas of active inflammation, especially in central areas of PGs and in the subepithelial region of RCs.

We observed immunostained giant cells at the periphery of the connective tissue portion, which represent macrophages in phagocytosis. Macrophages play complex roles in phagocytosis, in the production of inflammatory mediators, and in the activation of humoral and cellular immune responses (Rodini \& Lara, 2001). In addition to their effector functions, macrophages act as antigen-presenting cells and can trigger and regulate immune responses (Locati et al. 2013). These cells also play a key role during ontogenetic tissue differentiation and in tissue homeostasis and bone remodeling (Mantovani et al. 2013).

The products produced by bacteria and the immune response that acts on the periapex cause the destruction of periapical tissues and the consequent formation of osteolytic lesions (Graunaite et al. 2012). The presence of macrophages is also extremely important for the protective responses in chronic periapical lesions, as well as for the development and perpetuation of inflammatory reactions. The latter is the most important role of these cells in the protective response (Marton \& Kiss, 2000; Rodini \& Lara, 2001; Bănică et al. 2018). However, it was not possible to analyze this function of macrophages in the process of bone or root resorption in the cases studied. In addition, remnant bone at the periphery of the lesions was not present in all samples.

The detection of macrophages in the present study indicates their important role in the pathogenesis of PGs and RCs. These cells represent the first line of local defense, being not only involved in phagocytosis but also in the production of inflammatory mediators in response to bacterial proliferation in the root canals (Lin et al. 2000; Azeredo et al. 2017; Cassanta et al. 2017). This analysis suggests that macrophages are responsible for the development, maintenance and/or severity of the inflammatory process in these lesions.

The difference in the staining intensity and in the number and distribution of CD68+ cells observed between PGs and RCs indicates differences in the synthesis and/or activity of chemical mediators involved in the formation of these lesions, or the loss of antigenicity. Further studies using markers that identify inflammatory mediators in chronic periapical lesions are necessary to understand the true role of macrophages in these lesions.

\section{Conclusions}

The presence of CD68+ cells in chronic periapical lesions may represent the host-mediated immune response to inflammation, with this response being more intense in PG. The difference in the staining intensity and in the number and distribution of CD68+ cells observed between PGs and RCs indicates differences in the synthesis and/or activity of immune mediators involved in the development, persistence and/or severity of these lesions.

Therefore, this in vitro study contributes to better clarify the differences between periapical granulomas and radicular cysts. However, new studies about other inflammatory cells involved in the development of these lesion, as well as in vivo studies, must be conducted in order to evaluate the types of inflammatory responses. Thus, an enhanced understanding of the inflammatory process can assist in obtaining an appropriate treatment and a favorable prognosis. 


\section{Declaration of Competing Interest}

The authors declare that there are no conflicts of interest.

\section{References}

Álvares, P. R., Arruda, J. A. A., Silva, L. P., Nascimento, G. J. F., Silveira, M. M. F., \& Sobral, A. P. V. (2017). Immunohistochemical expression of TGF- $\beta 1$ and MMP-9 in periapical lesions. Brazilian Oral Research, 3, 31:e 51.

Alvares, P. R., Arruda, J. A. A., Silva, V. O., Silva, L. P., Nascimento, G. J. F., Silveira, M. M. F., \& Sobral, A. P. V. (2018). Immunohistochemical Analysis of Cyclooxygenase-2 and Tumor Necrosis Factor Alpha in Periapical Lesions. Journal of Endodontics, 44(12), 1783-87.

Azeredo, S. V., Brasil, S. C., Antunes, H., Marques, F. V., Pires, F. R., \& Armada, L. (2017). Distribution of macrophages and plasma cells in apical periodontitis and their relationship with clinical and image data. Journal of Clinical and Experimental Dentistry, 9(9), 1060-e1065.

Bănică, A. C., Popescu, S. M., Mercuţ, V., Busuioc, J. C., Gheorghe, A. G., Traşcă, D. M., Brăila, A. D., \& Moraru, A. I. (2018). Histological and immunohistochemical study on the apical granuloma. Romanian Journal of Morphology and Embryology, 59(3), 811-817.

Bracks, I. V., Armada, L., Goncalves, L. S., \& Pires, F. R. (2014). Distribution of mast cells and macrophages and expression of interleukin-6 in periapical cysts. Journal of Endodontics, 40(1), 63-8.

Cassanta, L. T. C., Rodrigues, V., Violatti-Filho, J. R., Teixeira Neto, B. A., Tavares, V. M., Bernal, E. C. B. A., Souza, D. M., Araujo. M. S., Lima, P. S. A de, \& Rodrigues, D. B. R. (2017). Modulation of Matrix Metalloproteinase 14, Tissue Inhibitor of Metalloproteinase 3, Tissue Inhibitor of Metalloproteinase 4, and Inducible Nitric Oxide Synthase in the Development of Periapical Lesions. Journal of Endodontics, 43(7), 1122-1129.

Cavalla, F., Letra, A., Silva, R. M. \& Garlet, G. P. (2021). Determinants of Periodontal/Periapical Lesion Stability and Progression. Journal of Dental Research, 100(1):29-36

Galler, K. M., Weber, M., Korkmaz, Y., Widbiller, M. \& Feuerer, M. (2021). Inflammatory Response Mechanisms of the Dentine-Pulp Complex and the Periapical Tissues. International Journal of Molecular Sciences, 2; 22(3): 1480

Graunaite, I., Lodiene, G., Maciulskiene, V. (2012). Pathogenesis of Apical Periodontitis: A Literature Review. Journal of oral e maxillofacial research, 2(4), 1011-23.

Koivisto, T., Bowles, W. R., \& Roherer, M. (2012). Frequency and distribution of radiolucent jaw lesions: a retrospective analysis of 9,723 cases. Journal of Endodontics, 38(6), 729-32.

Leonardi, R., Caltabiano, R., \& Loreto, C. (2005). Collagenase-3 (MMP-13) is expressed in periapical lesions: an immunohistochemical study. International Endodontic Journal, 38(5), 297-301.

Liapatas, S., Nakou, M., \& Rontogianni, D. (2003). Inflamatory infiltrate of chronic periradicular lesions: an immunohistochemical study. International Endodontic Jounal, 36(7), 464-71.

Li, J., Hsu, H. C., \& Mountz, J. D. (2013). The dynamic duo-inflammatory M1 macrophages and Th17 cells in rheumatic diseases. Journal of Rheumatology and Orthopedics, 1(1), 4.

Lin, S. K., Hong, C. Y., Chang, H. H., Chiang, C. P., Chen, C. S., Jeng, J.H., \& Kuo, M. Y. (2000). Immunolocalization of macrophages and transforming growth factor-beta 1 in induced rat periapical lesions. Journal of Endodontics, 26(6), 335-40.

Locati, M., Mantovani, A., \& Sica A. (2013). Macrophage activation and polarization as an adaptive component of innate immunity. Advances in Immunology, $120,163-84$

Maia, L.M., Espaladori, M.C., Diniz, J.M.B., Tavares, W.L.F., de Brito, L.C.N., Vieira, L.Q. \& Sobrinho, A.P.R. (2020). Clinical endodontic procedures modulate periapical cytokine and chemokine gene expressions. Clinical Oral Investigation, 24(10):3691-3697.

Mantovani, A., Biswas, S. K., Galdiero, M. R., Sica, A., \& Locati, M. (2013). Macrophage plasticity and polarization in tissue repair and remodelling. The Journal of Pathology, 229(2), 176-85.

Mantovani, A., Sica, A., \& Locati, M. (2007). New vistas on macrophage differentiation and activation. European Journal of Immunology, 37(1), 14-6.

Marton, I. J., \& Kiss, C. (2000). Protective and destructive immune reactions in apical periodontitis. Oral Microbiology and Immunology, 15(3), 139-50.

Metzger, Z. (2000). Macrophages in periapical lesions. Endodontic \& Dental Traumatology, 16(1), 1-8.

Rodini, C. O.; Batista, A. C.; \& Lara, V. S. (2004). Comparative immunohistochemical study of the presence of mast cells in apical granulomas and periapical cysts:Possible role of mast cells in the course of human periapical lesions. Oral Surgery, Oral Medicine, Oral Pathology and Oral Radiology, 97(1), 59-63.

Rodini, C. O., \& Lara, V. S. (2001). Study of the expression of CD68+ macrophages and CD8+ T cells in human granulomas and periapical cysts. Oral Surgery, Oral Medicine, Oral Pathology and Oral Radiology, 92(2), 221-7.

Suzuki, T., Kumamoto, H., Ooya, K., \& Motegi, K. (2001). Immunohistochemical analysis of CD1a-labeled Langerhans cells in human dental periapical inflammatory lesions--correlation with inflammatory cells and epithelial cells. Oral Diseases, 7(6), 336-43.

Weber, M., Schlittenbauer, T., Moebius, P., Büttner-Herold, M., Ries, J., Preidl, R., Geppert, C. I., Neukam, F.W., \& Wehrhan, F. (2018). Macrophage polarization differs between apical granulomas, radicular cysts, and dentigerous cysts. Clinical Oral Investigations, 22(1), 385-94. 